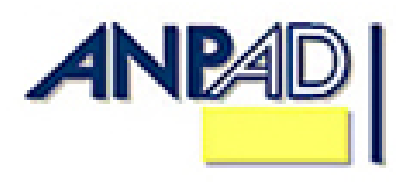

Available online at http://www.anpad.org.br/bar

BAR, Rio de Janeiro, v. 11, n. 1, art. 4, pp. 64-85, Jan./Mar. 2014

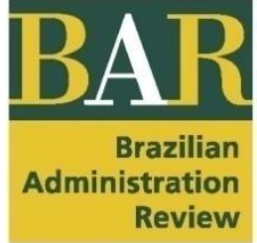

$(\mathrm{coc})$ Er-No

\title{
Dynamics of Competition and Survival
}

Renata Peregrino de Brito

E-mail address: renatap.brito@gmail.com Ibmec Rio de Janeiro Av. Pres. Wilson, 118, Rio de Janeiro, RJ, Brazil.

Luiz Artur Ledur Brito E-mail address: luiz.brito@fgv.br Fundação Getúlio Vargas - EAESP/FGV Fundação Getulio Vargas - EAESP, R. Itapeva, 474, 01332-000, São Paulo, SP, Brazil.

Received 11 December 2012; received in revised form 26 June 2013 (this paper has been with the authors for two revisions); accepted 4 July 2013; published online $2^{\text {nd }}$ January 2014. 


\begin{abstract}
Along time, increasing competitiveness is said to have shortened firms' life spans; however, for those who managed to survive, the question relies on what are the best competitive positions. The question is whether firms can sustain a competitive advantage for longer periods. To answer it, this article analyzes the combined performance (profit and growth) trajectories of 993 firms along two decades, comparing their competitive dynamics with the overall market. We use American COMPUSTAT data (1990-2009), decomposing the individual firm effect in hierarchical modeling and segregating the different strategic choices and transitions between advantage, disadvantage and parity along that period. The results reveal that most firms are unable to maintain advantage/disadvantage for longer periods. Moreover, the comparison between the 993 long-lived firms and the overall database reveals a more conservative profile of competitiveness of the former, suggesting different strategies between the groups.
\end{abstract}

Key words: competitiveness; survival; performance; multilevel analysis. 


\section{Introduction}

Competitive dynamics are well known for impacts on sustainability of advantage positions as well as in firm survival (Burgelman \& Grove, 2007). Along the last decades, macroeconomic fluctuations and the rise of new players from peripheral economies, as well as rapid technology innovation have altered the former competitive configuration among businesses (D'Aveni, Dagnino, \& Smith, 2010). One of the effects of this increasing competitiveness is the shortening of firms' life spans, but for those who manage to survive, the question is how to find the most adequate competitive position. In this article we discuss the dynamics of competitiveness among firms that managed to survive for the last two decades, analyzing their pathways, variations and stability along that period.

Competitive dynamics, also studied under the theme hypercompetition (D'Aveni, 1994), has been broadly discussed in the business strategy field and investigated in econometric models, with inconclusive findings. While McNamara, Vaaler and Devers (2003) found no evidence of hypercompetition, Wiggins and Ruefli (2005) demonstrated that competitive advantage has become increasingly harder to sustain. Meanwhile, other studies suggest that the industry leadership rotation might be intentionally provoked by leaders in a self-displacement movement (Pacheco-de-Almeida, 2010). These studies, mostly anchored in the observation of profitability variables to measure competitive advantage, suggest different conclusions about the theme.

In fact, the study of competitiveness itself raises several conceptual and methodological issues. Theoretically, competitive advantage has been defined as superior value creation (Ghemawat \& Rivkin, 2006), and yet most of the empirical evidences rely on proxies for value appropriation and profitability metrics. Such procedures do not capture the entirety of value creation performance effects (Brito \& Brito, 2012). The value portion left to the customer promotes growth, so a combined measure including both growth and profitability is necessary to infer about competitive advantage.

Value creation is particularly important in longitudinal studies, where the development of capabilities depends on the interaction with business partners (Teece, Pisano, \& Shuen, 1997). Different capabilities are necessary to navigate technology transitions, and firms must recycle and redeploy resources along time to survive and prosper (Helfat \& Peteraf, 2003). On this path, the ability to balance exploitation and exploration capabilities, also known as organizational ambidexterity, is crucial (Burgelman \& Grove, 2007; Taylor \& Helfat, 2009). In light of disruptive contexts, firms may prefer growth or profitability at different moments.

Therefore, competitive dynamics cannot be addressed by the investigation of single longitudinal performance results. Apart from the fundamental profit objective, firm's success is in its capacity of creating value, which encompasses a wider range of performance results. In that sense, this paper studies the dynamics of competitiveness through the longitudinal financial analysis of combined performance results. The performance variables of growth and profitability are analyzed in a model that allows the identification of different strategic choices of value creation and appropriation, in situations of advantage, disadvantage and parity. The main contributions of this study rely on the direct observation of firms' competitive trajectories and different patterns of positioning.

We start this paper with a theoretical background on competitive advantage and the dynamics of competitiveness over time. We also analyze the theoretical implications of the relationship between profit and growth. To measure competitiveness, we apply a multilevel model to estimate firm-specific performance effects and track their evolution along time (Brito \& Brito, 2012).

To analyze firm survival, the model is applied to a sample of 993 firms that remained operative along the period between 1990 and 2009. The results are compared to a second sample of 6,810 transient firms that were active along that same period. Performance results were decomposed into firm and industry averages through a multilevel hierarchical model, and firm performance combined growth and profitability outcomes. Results are further discussed as to how sustainable competitive positions were and what were the main paths chosen by the firms in each sample. 


\section{Theoretical Background}

\section{Value creation, competitive advantage and performance}

One of the first voices to differentiate the concepts of competitive advantage and superior performance was Russ Coff in his article: "When competitive advantage doesn't lead to performance" (Coff, 1999, p. 119). The author argued that rents generated by a firm may be appropriated by internal stakeholders, such as employees demanding higher salaries, and may not result in superior financial performance. In such cases, competitive advantage does not necessarily result in superior profits (Powell, 2001), a debate that leads to the conceptual differentiation between competitive advantage and value creation from performance (Besanko, Dranove, Shanley, \& Schaefer, 1996; Brandenburger \& Stuart, 1996).

The definition of competitive advantage has slowly converged towards the economic concept of superior value creation; whereas value is further detailed into use value and exchange value (Bowman \& Ambrosini, 2000; Lippman \& Rumelt, 2003). Use value is defined by the limits between suppliers' opportunity cost and customers' willingness to pay, which comprehends the boundaries of value creation (Brandenburger \& Stuart, 1996). Exchange value is defined by the limits of cost and price, and configures the value appropriated by the firm (Figure 1).

Value creation is a function of firm resources and capabilities as well as its interaction with business partners (Bowman \& Ambrosini, 2000; Peteraf \& Barney, 2003). This approach to value creation has been further developed in related areas such as operations management (Crook \& Combs, 2007) and marketing (Lindgreen \& Wynstra, 2005; Vargo \& Lusch, 2004). The boundaries of value creation have been extensively studied as buyer-supplier relationships, as well as customer relationships.

Thus, as a landmark of firm superiority, competitive advantage is the situation where a firm creates more value than its average competitor during a defined length of time.

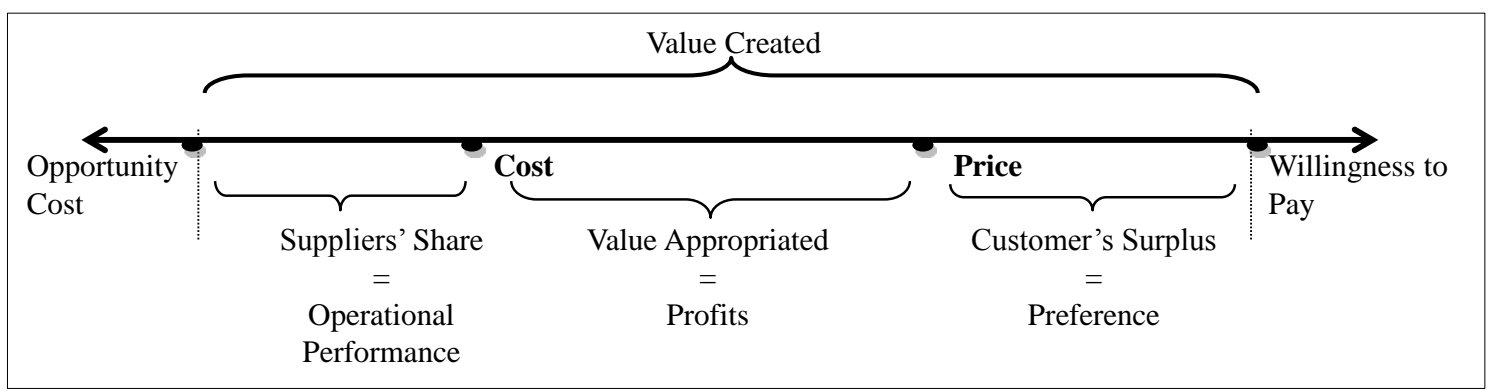

Figure 1. Value Creation and Value Appropriation.

Source: Adapted from Brandenburger, A. M., \& Stuart, H. W., Jr. (1996). Value-based business strategy (p. 10). Journal of Economics \& Management Strategy, 5(1), 5-24. doi: 10.1111/j.1430-9134.1996.00005.x

Following the argument, it can be understood from Figure 1 that value created by a firm is composed of three elements: the supplier's share (the difference between cost and the opportunity cost), the value appropriated, and the customer's surplus (a value left to the customer as a motivation for purchase).

The relationship between value appropriation and financial performance is straightforward. If a firm has a strong bargaining position with suppliers and/or customers it will be able to push the price higher or the cost lower and, consequently, increase its profit. Thus, firms that are able to appropriate more value than their counterparts should exhibit higher profitability. This might come as a consequence of higher value creation, in which case it would be an indication of competitive advantage. However it may also be a simple consequence of bargaining power, in which case it would 
happen at the expense of business partners (customers and or suppliers) jeopardizing the firm's competitive position.

The customer's surplus is not negligible. It is the result of a superior product or service offered and serves as a transaction driver (Priem, 2007). Customers give preference to the offer that brings a better value/price relation. If a firm consistently offers more value to customers than its competitors, it is likely that it will gain market share and thus grow more rapidly than the market average. Therefore, the direct effect of the customer's surplus in financial performance is superior sales growth and a gain in market share.

On the other side of the chain, the supplier's share is an important conductor of organizational performance. Cooperation among suppliers is a source of innovation, quality improvements, and cost reduction over time, also known as relational rents (Dyer \& Singh, 1998).

This paper drives from the logic of these direct effects of superior value creation over financial performance. We assert that firms with competitive advantage are able to manage their results of profitability and growth and balance their choices in accordance with the market opportunities. On the other hand, firms with inferior value creation can only achieve higher growth if they sacrifice profitability and vice-versa. Therefore, we drive our investigation from a dynamic perspective in which financial performance varies (within limits) and competitiveness is the focus of analysis.

\section{Dynamics of competition}

The dynamics of competition and the evolution of resources and capabilities in time have been long studied and exemplified in cases such as Apple's success, or in Kodak's difficulties or even in IBM's business transition (Coff, 2010; Taylor \& Helfat, 2009). These long-lived firms faced environmental challenges over time, to which they responded differently. It is possible that all firms experienced successful and unfortunate business decisions in time; however the quest is for strategies that can yield advantage in the long run.

Sustained competitive advantage was introduced as one that yields superior performance over the long run (Porter, 1985). Yet, some authors have questioned not only the existence of competitive advantage, but also its capacity in sustaining superior performance over time (D'Aveni et al., 2010; Powell, 2001). The phenomenon of Schumpeterian hypercompetition implies that high-velocity and turbulent markets would hamper the capacity of maintenance of competitive position (McNamara, Vaaler, \& Devers, 2003; Wiggins \& Ruefli, 2005). Finally, studies suggest that market context would only provide opportunities for temporary advantages.

There have been numerous drivers for fast-paced competition, among them technological change, globalization and aggressive competitive behavior (D'Aveni et al., 2010). In that scenario, entrants and incumbents have different approaches towards competition. Entrants are well known for imposing new competitive dynamics, whereas incumbents are normally identified as having strong inertia (Burgelman \& Grove, 2007). Among others, the structural conditions do not change rapidly and organizations tend to keep their strategy over time (Geroski, Mata, \& Portugal, 2010).

Business inertia can be favorable to incumbents, in shaping and maintaining the parameters of competition in favor of industry leaders (Burgelman \& Grove, 2007). In that case, long-lived companies tend to accumulate assets and market power, so as to gain from larger economies of scale and endure through competitive times (Geroski et al., 2010). On the other hand, organizational ecology theory suggests that structural inertia implies greater difficulties in handling dynamic environments, and over time long-lived companies would be overtaken by new entrepreneurial organizations (Hannan \& Freeman, 1984). Therefore, it emphasizes the importance of not only surviving but also remaining competitive over time (Fleck, 2004).

The analysis of competitiveness over time reveals that firms have to deploy different resources and capabilities to be successful. In the search for competitive advantage, firms must invest and 
deploy strategic assets to explore new market opportunities and or exploit existing businesses and products (Cao, Gedajlovic, \& Zhang, 2009; Taylor \& Helfat, 2009). Indeed, competitive dynamics impose more than the capacity for adaptation, but also the development of new capabilities to survive the changing environment (Teece et al., 1997). The organizational ambidexterity calls for simultaneous exploration of business opportunities; i.e. introducing new generations of products or opening up new markets, as well as the exploitation of existing products attributes and flexibilities (Cao et al., 2009). These organizational capabilities rely on management cognitive capacity and organizational linkages between units for the development of new technologies and complementary assets (Taylor \& Helfat, 2009). Managerial decisions alternate between exploiting well-established products and services, or in exploring new markets, or even in combining both strategies simultaneously. Exploration and exploitation strategies were initially considered to be exclusive choices (March, 1991). However recent studies have not confirmed that hypothesis and empirical evidence suggest that the constraining factor is in resource availability (Cao et al., 2009).

In face of market and technological changes, managers should be able to balance strategies and combine antagonistic and complementary resources and capabilities (Fleck, 2010). In the process of resource deployment, internal and external events may reinforce or change the trajectory and lead to reconfiguration of resources (Helfat \& Peteraf, 2003). Eventually, resources and capabilities will meet the end of their lifecycle and new deployment must take place.

The timing for development of resources and capabilities varies across firms and industries, so does the revelation of performance results (Coff, 2010). Competitive times call for better management of value created, in protecting market participation and supplier collaboration, driving different performance results. The alternating periods of market expansion and cycles of technology changes offer different opportunities for the monetization of value created and performance results (Coff, 2010). These results have to be observed jointly in composition and complementarity.

\section{Performance effects: profit and growth}

Profit and growth are important financial performance results. Early empirical studies in business strategy, such as the Profit Impact of Marketing Strategy (PIMS) program, studied the relation between profitability and growth. In general, the studies focused on investigating market share, among other factors, as explanatory variables for profit level (Jacobson, 1990). In its 15 years of research, the PIMS study results were positive in terms of the relationship between the variables (Buzzell, 2004).

It is presumed that successful firms are able to maximize both market share and profitability potentials (Steffens, Davidsson, \& Fitzsimmons, 2009). As sales growth and profitability compose a firm's free cash flow, there is an understanding of complementarity between them. However, as growth and profitability originate from the same resources, there is also a notion of competition between the two objectives.

The balance between complementarity and competition of profit and growth has been explored in economic studies. The relationship is often described in an inverted U-shape curve (Cubbin \& Leech, 1986), in which the point of growth maximization is given by the availability of financial resources, however beyond that point it is subject to diminishing marginal returns. The model implies a trade-off relationship.

More than a simple discussion of complementarity or competition, the relationship between growth and profitability is subjected to the influence of firm specificities and market conditions. The main debates around the growth-profitability relationship can be grouped into four major categories:

1. the limits of resources and management capacity, in which growth is constrained by a firm's managerial capacity; this is the assertion of so called Penrose Effect (Marris, 1964; Penrose, 1959); 
2. management agency, in which growth is favored by managers as a source of better remuneration and carrier opportunities (Jensen, 1986);

3. specificities of institutional context as well as market conditions that may favor business expansion in a given period (Baumol, 1962; Peng \& Heath, 1996); and

4. a firm's specific size and age, in which growth opportunities are preferred to profit (Steffens et al., 2009).

From these approaches we can conclude that the relationship between growth and profitability cannot be analyzed and determined in absolute conditions. The specificity of firm resources and maturity as well as the competitive context are important mediators of such relationships. Above all, in choosing strategies of profitability or growth, managers should be aware of the market opportunities for exploration and exploitation movements.

\section{Combined performance model}

Following the theoretical discussion, we apply a model of combined performance to capture the effects of competitive advantage (Brito \& Brito, 2012). In this model the performance effects of value creation can be captured in results of value appropriation, namely profitability, and market expansion. Therefore, the model is sensitive to broader results of a firm's strategic decisions. Among others, agency issues and incentive systems may lead managers to prioritize growth of profitability in specific situations (Jensen, 1986; Peng \& Heath, 1996).

The model, summarized in Figure 2, also considers the possibility of trade-off, meaning cases in which one performance result implies the decline of the other. However, firms with competitive advantage create superior value, and should be able to:

1. practice premium prices, appropriating more value, resulting in abnormal profitability while maintaining their market share;

2. expand their market share, offering more value to customers, while maintaining profitability within industry average, or both;

3. appropriate more value, increasing profitability and yet allow their customers a surplus, hence expanding their market share at the same time.

Firms with competitive advantage should be located at the upper-right frontier in the model, and their performance results (profit or growth) should never decay below the industries average. On the other extreme, competitive disadvantage is given by the configuration of profit or growth either separately or jointly below industry average. Within the interval of industry average performance are those firms classified as in competitive parity. Finally the firms in trade-off performances, either with above normal profit and below normal growth or with above normal growth and below normal profit are classified as profit focus or growth focus. 


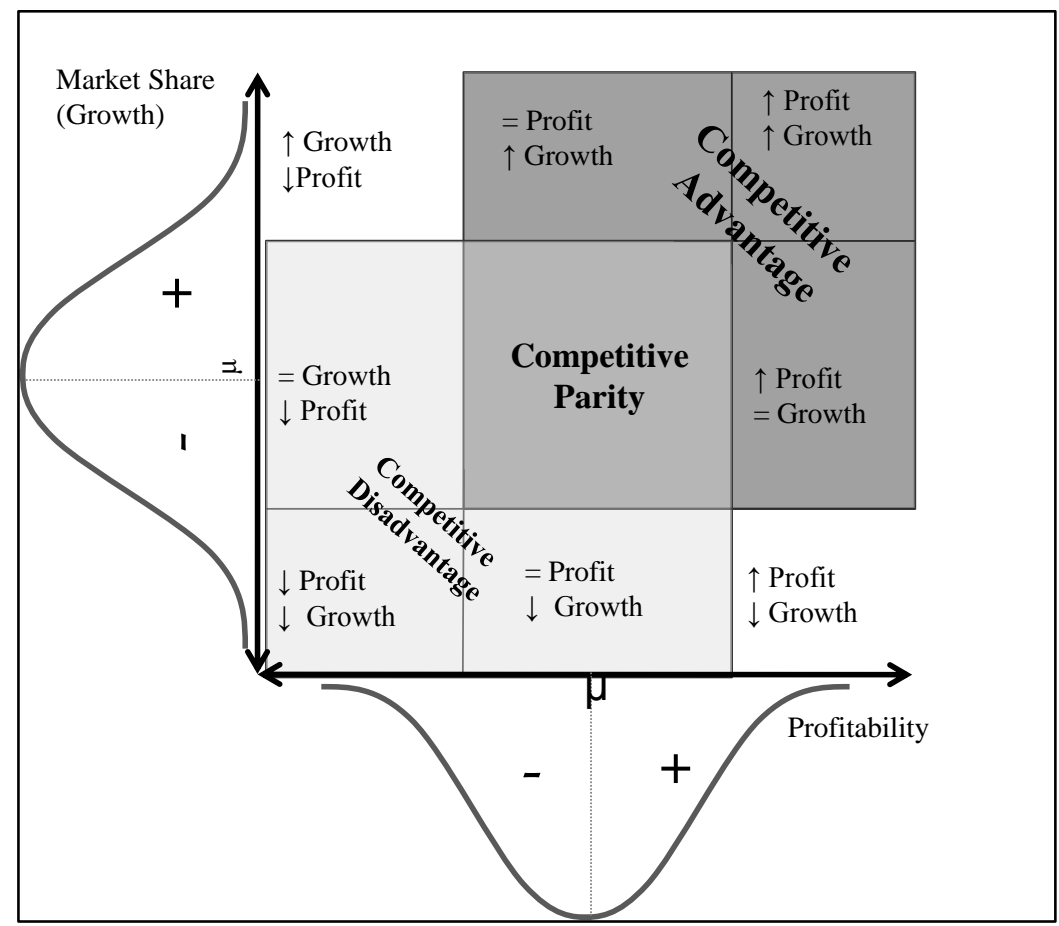

Figure 2. Model Combined Performance.

Source: Adapted from Brito, R. P. de, \& Brito, L. A. L. (2012). Vantagem competitiva, criação de valor e seus efeitos sobre o desempenho (p. 76). Revista de Administração de Empresas, 52(1), 70-84. doi: 10.1590/S0034-75902012000100006

The longitudinal analysis must be aligned with the time perspective for resource deployment and consequent value creation. Although business lifecycles vary between industries, we have considered the management planning horizon of five years as a valid interval for the observation of value creation effects on performance (Powell, 2003). Within this time frame, each firm's performance was compared against industry average and classified in the model.

\section{Data and Method}

\section{Data}

The model was applied to a database extracted from COMPUSTAT (Standard \& Poor's), corporations, covering the period from 1990 to 2009, with both active and historic information. A total of 27,343 companies were initially extracted, covering 447 industries (four digit Standard Industrial Classification $[\mathrm{SIC}])$. The database was submitted to a debugging process as follows:

1. Following McGahan and Porter (1997), we excluded financial services as well as government and non-classified business and eliminated firms with assets or revenues under US\$10 million to allow comparability.

2. To balance the industry average, we eliminated sectors with less than five companies and firms with less than five years of continuous observations. Since our focus is to establish competitive advantage, we judged that only industries with several competitors could be considered. This excludes monopoly and most oligopoly situations.

At that point our sample was composed of 6,810 firms from which we selected a sub-set of firms that remained active along 1990-2009, these 993 firms, from 156 industries, are referred as selected firms. To analyze firms' competitiveness over time, we compared the dynamic of those 
selected firms to the overall dynamic of the database. The competitive evolution along the 20 years was observed in the transitions along the four sets of five year intervals (Table 1).

Table 1

Number of Firms and Industries

\begin{tabular}{lccccc}
\hline & Total & $\mathbf{1 9 9 0 - 9 4}$ & $\mathbf{1 9 9 5 - 9 9}$ & $\mathbf{2 0 0 0 - 0 4}$ & $\mathbf{2 0 0 5 - 0 9}$ \\
\hline Database & 6,810 & 3,061 & 3,756 & 3,681 & 3,010 \\
Selected Firms & 993 & & & & \\
Industry Sectors & 156 & & & & \\
\hline
\end{tabular}

Along the period analyzed, we noted strong entry movements and the exclusion of firms in the database. This renovation process can be partially attributed to mergers and acquisitions, bankruptcy liquidation movements and to the procedure of database debugging as described above. On average, one-third of the database was renewed in each interval, whereas the 993 selected firms not only remained operational, but maintained their identification along period 1990 to 2009. Long-lived, these selected firms accounted for only $15 \%$ of the sample, however we acknowledge that there might be other firms with this same profile that were eliminated because of industry screening (not enough participants in a given industry) or could not be recognized due to changes in their identification number (Gvkey).

Table 2

Analysis of Database Transient Firms

\begin{tabular}{lcclcc}
\hline & $\mathbf{N}$ & $\mathbf{\%}$ & Transient Firms & $\mathbf{N}$ & $\mathbf{\%}$ \\
\hline Total Database & 6,810 & $100 \%$ & Mergers \& Acquisitions* & 2,257 & $39 \%$ \\
Selected Firms & 993 & $15 \%$ & Liquidation \& Bankruptcy* & 131 & $2 \%$ \\
Transient Firms & 5,817 & $85 \%$ & Closed Capital* & 59 & $1 \%$ \\
& & & Other* & 592 & $10 \%$ \\
& & & Database debugging & 2,778 & $48 \%$ \\
\cline { 3 - 6 } & & & Transient Firms: & 5,817 & $100 \%$ \\
\hline
\end{tabular}

Note. *Informed by S\&P Capital IQ - McGraw Hill Financial. (n.d.). Data base (COMPUSTAT). Retrieved from https://www.capitaliq.com/home/what-we-offer/what-you-can-do-with-it/streamline-quantitative-research/researchinsight.aspx

The initial analysis of the selected firms confirms the main postulates about firm longevity and size (Fleck, 2004). On average, the selected firms were superior in terms of size as measured in total assets (Table 3). 
Table 3

Comparing Size: Selected Firms and Database

\begin{tabular}{llccccc}
\hline \multicolumn{2}{l}{ Size (Assets US\$ millions) } & Average & $\mathbf{1 9 9 0 - 9 4}$ & $\mathbf{1 9 9 5 - 9 9}$ & $\mathbf{2 0 0 0 - 0 4}$ & $\mathbf{2 0 0 5 - 0 9}$ \\
\hline \multirow{2}{*}{ Selected Firms } & Mean & 7,408 & 4,019 & 5,470 & 8,713 & 11,429 \\
& Std.Dev & 21,000 & 12,687 & 16,425 & 25,484 & 29,404 \\
\multirow{2}{*}{ Database } & Mean & 3,789 & 2,321 & 2,594 & 4,230 & 6,012 \\
& Std.Dev & 13,518 & 8,591 & 10,057 & 15,628 & 19,796 \\
\hline
\end{tabular}

Regarding the competitive environment, the distribution by industrial sectors followed the pattern of the extracted database (after exclusion of financial services, government and non-classified business), except for the services sector that appeared underrepresented in that group (Table 4).

Table 4

Comparing Industry Distribution: Selected Firms and Database

\begin{tabular}{lcc}
\hline SIC Divisions & Selected Firms & Database \\
\hline A - Agriculture, Forestry, And Fishing & $0.40 \%$ & $0.27 \%$ \\
B - Mining & $5.04 \%$ & $5.18 \%$ \\
C- Construction & $2.22 \%$ & $1.41 \%$ \\
D - Manufacturing & $47.33 \%$ & $45.85 \%$ \\
E - Transportation, Communications, Electric, Gas, And Sanitary Services & $25.28 \%$ & $17.88 \%$ \\
F - Wholesale Trade & $2.62 \%$ & $3.63 \%$ \\
G - Retail Trade & $7.35 \%$ & $8.51 \%$ \\
I - Services & $9.77 \%$ & $17.21 \%$ \\
Total number of firms & 993 & 6,810 \\
\hline
\end{tabular}

\section{Variables}

Variables were depicted from the theoretical framework, aiming at capturing the direct effects of value creation upon performance. Profitability was operationalized by the accounting measure of return on assets (ROA), most widely applied in business strategy, a sensitivity test was conducted with the variable return on sales showing no significant difference.

Growth followed the operationalization used by Helfat et al. (2007) for the calculation of the compounded sales growth rate for each interval:

$$
\mathrm{S}_{\mathrm{t}}=\mathrm{S}_{0}(1+\mathrm{g})^{\mathrm{t}}
$$

where $\mathrm{S}=$ sales value and $\mathrm{g}=$ average growth rate for period $\mathrm{t}$.

With the logarithmic transformation we have:

$\log S_{t}=\log S_{0}+$ t. $\log (1+g)$

Since the model evaluated the firm-effect of growth, it removes the growth associated with industry and can be taken as the variation in market share ( $\triangle \mathrm{MS})$ for those companies relative to the others. 
Correlation coefficients between the variables along the four interval samples were significant and positive, which does not indicate a trade-off relationship between profit and growth for the database.

Table 5

Correlation Matrix and Descriptive Statistics for the Database

\begin{tabular}{lcccccccc}
\hline & ROA & ROA & ROA & ROA & Growth & Growth & Growth & Growth \\
& $1990-94$ & $1995-99$ & $2000-04$ & $2005-09$ & $1990-94$ & $1995-99$ & $2000-04$ & $2005-09$ \\
\hline ROA 1990-94 & 1 & & & & & & & \\
ROA 1995-99 & $.447^{* *}$ & 1 & & & & & & \\
ROA 2000-04 & $.324^{* *}$ & $.385^{* *}$ & 1 & & & & & \\
ROA 2005-09 & $.206^{* *}$ & $.251^{* *}$ & $.450^{* *}$ & 1 & & & & \\
Growth 1990-94 & $.306^{* *}$ & $.067^{* *}$ & .037 & -.009 & 1 & & & \\
Growth 1995-99 & $.072^{* *}$ & $.118^{* *}$ & -.040 & -.043 & $.195^{* *}$ & 1 & & \\
Growth 2000-04 & $.068^{*}$ & -.018 & $.150^{* *}$ & $.085^{* *}$ & .003 & .022 & 1 & \\
Growth 2005-09 & .005 & $-.091^{* *}$ & -.027 & $.102^{* *}$ & .033 & .021 & .146 & 1 \\
\hline Mean & 2.35 & 2.38 & -.73 & 1.0686 & 7.93 & 13.83 & 7.01 & 8.75 \\
Std. Deviation & 7.51 & 9.22 & 12.49 & 11.52 & 14.14 & 20.30 & 14.35 & 15.84 \\
$\mathrm{~N}$ & 3,061 & 3,756 & 3,681 & 3,010 & 3,061 & 3,756 & 3,681 & 3,010 \\
\hline
\end{tabular}

Note. $* \mathrm{p}<.05 . * * \mathrm{p}<.001$

\section{Multilevel model and estimation of firm effects}

The analysis of the individual performance of each firm was conducted by decomposing the variables into firm and industry effects. For that purpose, we applied a multilevel model, isolating the firm effect and comparing the firms' performance in absolute terms. Using Raudenbush and Bryk (2002) notation, the three levels of the hierarchical model for profitability is as follows:

1. Level-1: $R O A_{i j k}=\pi_{0 j k}+\mathrm{e}_{\mathrm{ijk}}$

2. Level -2: $\pi_{0 j k}=\beta_{00 k}+r_{0 j k}$

3. Level -3: $\beta_{00 \mathrm{k}}=\gamma_{000}+\mathrm{u}_{00 \mathrm{k}} \cdot$ where

In the first level, $\mathrm{ROA}_{\mathrm{ijk}}$ is the ROA for company $\mathrm{j}$, at the time $i$, industry $\mathrm{k} ; \pi_{0 \mathrm{jk}}$ is the average ROA for the company $j$ (along five years) and $e_{i j k}$ represents the variance across time. The average ROA can be further decomposed into $\beta_{00 \mathrm{k}}$, as the average ROA for the industry $\mathrm{k}$ and the level 2 residual $\mathrm{r}_{0 \mathrm{jk}}$, as the difference between each company's performance and its industry average. It is assumed that $r_{0 j k}$ is normally distributed with mean zero and variance $\sigma_{\mathrm{r}}^{2}$, we will further refer to it as the firm component $\left(\mathrm{ROA}_{\mathrm{f}}\right)$. In the third level the ROA between-industries, $\beta_{00 k}$ is modeled in a grand mean, $\gamma_{000}$, and a residual random variation, $\mathrm{u}_{00 \mathrm{k}}$, for each industry.

Modeling growth, as the market share variation $(\Delta \mathrm{MS})$, required the insertion of a slope coefficient for each company. The slope coefficient in the first level represents the compound growth rate $(\mathrm{g})$ in the observed period as detailed below:

1. Level -1: $\log S_{i j k}=\left[\pi_{0 j k}+\pi_{1 j k}(\right.$ time $\left.)\right]+\mathrm{e}_{\mathrm{ijk}}$ 
2. Level $-2: \pi_{0 j k}=\beta_{00 k}+r_{0 j k}$

$$
\pi_{1 j k}=\beta_{10 k}+r_{1 j k}
$$

3. Level -3: $\beta_{00 k}=\gamma_{000}+u_{00 k}$

$$
\beta_{10 k}=\gamma_{100} \text {, where: }
$$

In the first, level $\log S_{i j k}$ represents the logarithm for sales of company $j$, at the time $i$, in industry k. Since time was centered, $\pi_{0 j k}$ stands for the logarithm of sales for company $j\left(\log S_{0}\right.$ as previously defined) when time is zero (the middle of the time period); $\pi_{1 j \mathrm{k}}$ represents the average growth rate, more precisely $\log (1+\mathrm{g})$ as previously detailed; and $e_{\mathrm{ijk}}$ is a random variation. In the second level, the parameters are decomposed into average industry logarithm for sales $\beta_{00 \mathrm{k}}$ and firm residual $\mathrm{r}_{0 \mathrm{jk}}$; and the average industry logarithm for sales variation, $\beta_{10 k}$, and firm residual $r_{1 j k}$. The firm residual, $r_{1 j k}$, is assumed as normally distributed with mean zero and variance $\sigma_{\mathrm{rl}}{ }^{2}$, and once reverted, the logarithm equation $(\log (1+\mathrm{g}))$ can be referred to as the firm's market share variation $(\Delta \mathrm{MS})$. The variance between-industry is represented in the third level.

This model was applied four times (once for each 5-year period) to all the firms in the database, which includes the selected firms.

The parameters considered for the prediction of each individual company performance are associated with the residual distributions. These parameters were estimated per the empirical Bayes prediction method, which combines the likelihood estimates with the values of prior distribution. The Bayesian estimator (also known as shrinkage estimator) reduces values proportionately to their level of reliability. Since the sample is unbalanced, this reduction may vary by firm (Raudenbush \& Bryk, 2002). As a consequence, the Bayesian estimator can generate good estimates independent of the number of participants at each level. The method also provides the variance of the estimates so that we could test the significance of the values against each industry mean, and compare companies' results across different industries. An important limitation, however, is that for this test the method assumes homogeneity of performance variance among firms, which we know is not true. Ad hoc tests suggest that low performance tends to be associated with larger variance and superior performance with smaller variance. This may tend to underestimate the number of firms with competitive advantage and overestimate those with competitive disadvantage. Another important limitation is the assumption of normality. Performance distributions have reasonable levels of kurtosis and asymmetry.

\section{Results and Discussion}

The multilevel modeling decoupled the performance into and firm results of $\mathrm{ROA}_{\mathrm{f}}$ and $\Delta \mathrm{MS}$, which were further tested $(\alpha=5 \%)$ against the respective industry average and categorized as regular, under or above normal performance. The process was repeated for the four intervals for the full database, and for each interval the threshold of performance was calculated in accordance with the variance of the parameters. Once the combined performance was calculated, we isolated the group of selected firms and compared their configuration with the full database. In this session we will start by comparing results between the selected firms and the database in each interval and in sequence we discuss the firms' migration between positions.

\section{The demography of competitiveness}

The analysis of the combined performance curves reveals the demography of competition for selected firms and the overall database. Figure 3 illustrates the plot for the firm performance distribution along the interval from 2005 to 2009; values are already decoupled from industry 
averages. In both samples, there is a strong concentration of firms within the industries' averages, and in both distributions it is possible to spot firms positioned outside the performance threshold in above or under average performance.

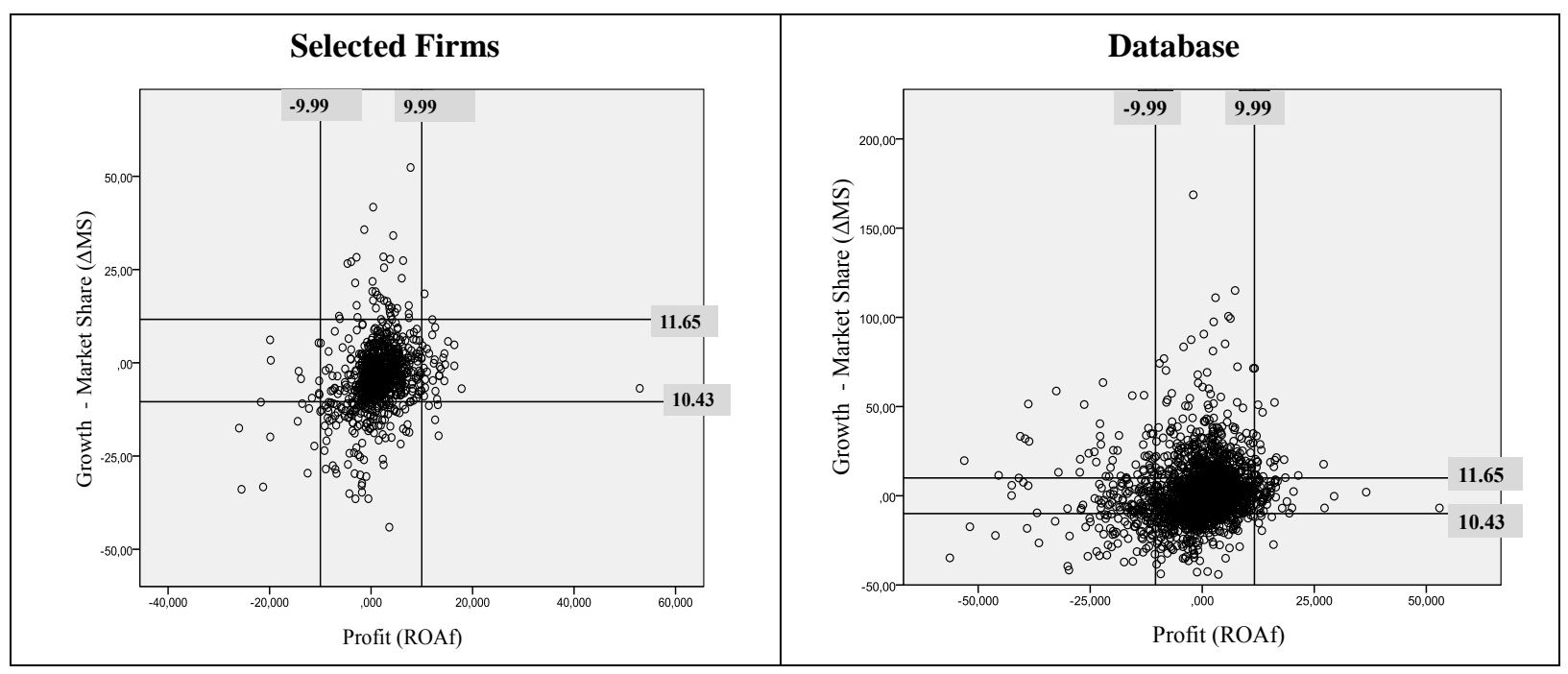

Figure 3. Combined Performance Distribution for 2005-09 Interval.

A more detailed analysis of distribution of firms along the competitive thresholds evidences the frequency of both advantage and disadvantage as well as parity between the two samples, however with some differences (Figure 4).

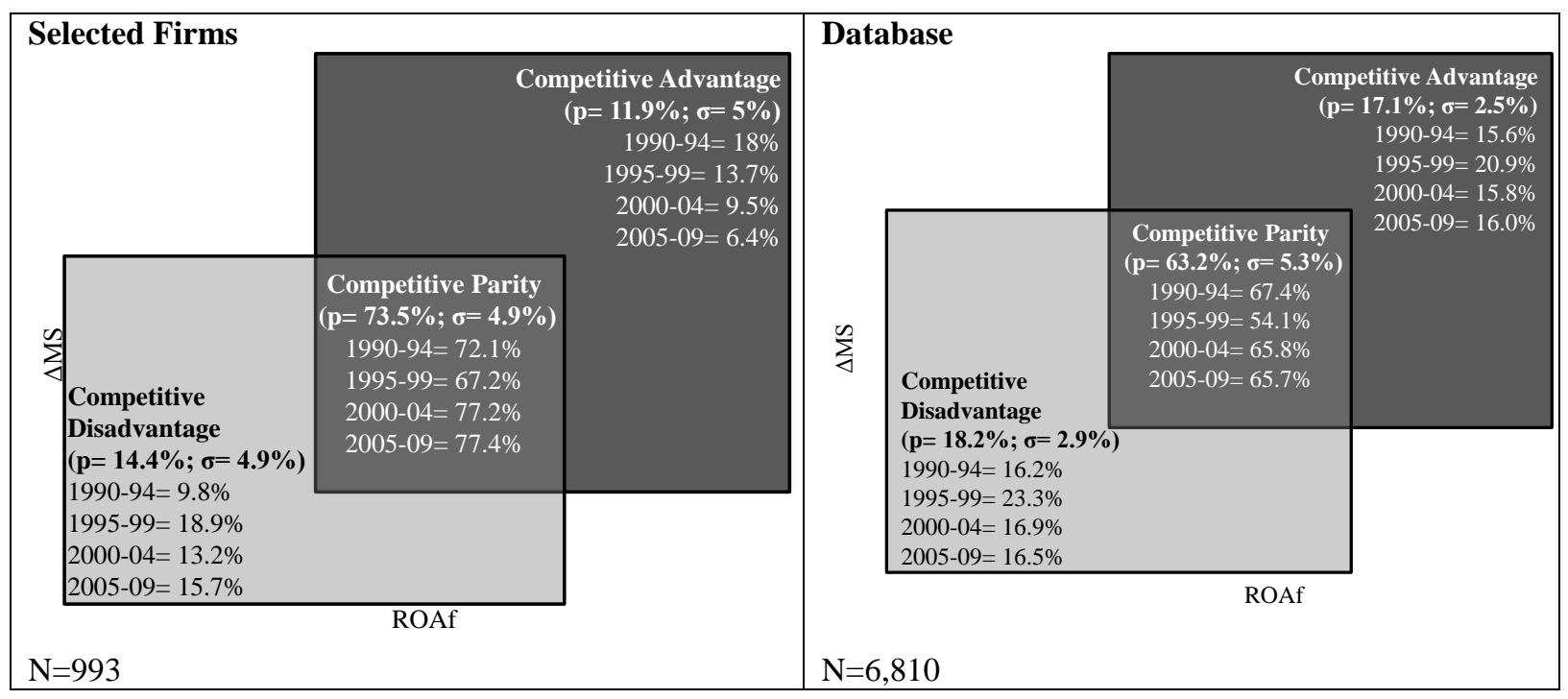

Figure 4. Competitive Configuration.

Along the 20 years, $11.9 \%(\sigma=5 \%)$ of the selected firms versus $17.1 \%(\sigma=2.5 \%)$ of the database were positioned in competitive advantage. On the other side, the competitive disadvantage covered $14.4 \%(\sigma=4.9 \%)$ of the selected firms versus $18.2 \%(\sigma=2.9 \%)$ of the database. In most occasions, $73.5 \%(\sigma=4.9 \%)$, the selected firms were classified in competitive parity. In comparison with the full database, results reveal a more conservative profile of the selected firms, among which parity concentration was 10 basis-points above that of the database, $63.2 \%,(\sigma=5.3 \%)$. 
Table 6

Results Combined Performance - Detailed Position

\begin{tabular}{llcccc}
\hline Position & & \multicolumn{2}{c}{ Selected Firms } & \multicolumn{2}{c}{ Database } \\
\hline Aggregated & Detailed & $\mathbf{p}$ & $\boldsymbol{\sigma}$ & $\mathbf{p}$ & $\boldsymbol{\sigma}$ \\
\hline Competitive & $\uparrow \mathrm{ROA}_{\mathrm{f}} \&=\Delta \mathrm{MS}$ & $2.7 \%$ & $0.7 \%$ & $2.6 \%$ & $0.5 \%$ \\
Advantage & $=\mathrm{ROA}_{\mathrm{f}} \& \uparrow \Delta \mathrm{MS}$ & $7.8 \%$ & $3.2 \%$ & $13.2 \%$ & $2.6 \%$ \\
& $\uparrow \mathrm{ROA}_{\mathrm{f}} \& \uparrow \Delta \mathrm{MS}$ & $1.4 \%$ & $1.5 \%$ & $1.3 \%$ & $0.5 \%$ \\
Competitive Parity & $=\mathrm{ROA}_{\mathrm{f}} \&=\Delta \mathrm{MS}$ & $73.5 \%$ & $4.9 \%$ & $63.2 \%$ & $6.1 \%$ \\
Competitive & $\downarrow \mathrm{ROA}_{\mathrm{f}} \& \downarrow \Delta \mathrm{MS}$ & $0.9 \%$ & $0.1 \%$ & $3.0 \%$ & $0.5 \%$ \\
disadvantage & $=\mathrm{ROA}_{\mathrm{f}} \& \downarrow \Delta \mathrm{MS}$ & $12.7 \%$ & $4.4 \%$ & $12.2 \%$ & $3.7 \%$ \\
& $\downarrow \mathrm{ROA}_{\mathrm{f}} \&=\Delta \mathrm{MS}$ & $0.8 \%$ & $0.7 \%$ & $3.0 \%$ & $0.5 \%$ \\
Focus & $\uparrow \mathrm{ROA}_{\mathrm{f}} \& \downarrow \Delta \mathrm{MS}$ & $0.2 \%$ & $0.1 \%$ & $0.2 \%$ & $0.1 \%$ \\
& $\downarrow \mathrm{ROA}_{\mathrm{f}} \& \uparrow \Delta \mathrm{MS}$ & $0.0 \%$ & $0.0 \%$ & $1.2 \%$ & $0.4 \%$ \\
\hline
\end{tabular}

Note. " $\uparrow "$ "above average, “ $\downarrow "$ below average and "=" within average performance $(p<.05)$.

In terms of performance effects of value creation, the detailed results demonstrate the predominance of growth advantage in both databases (7.8\% in selected firms and $13.2 \%$ in database), with more firms with above average growth and average ROA. Privileging growth can be an outcome of management agency (Jensen, 1986); but also a choice to embrace opportunities of businesses expansion (Baumol, 1962). In any case, these firms did manage to keep profitability within the industry average and therefore it cannot be clearly configured as a trade-off relation. This difference between growth and profitability could also be influenced by differences in the distributions, mainly kurtosis. Again this could be explored in future studies that remove the normality assumption.

On the other hand, a considerable proportion of firms in competitive disadvantage seemed to have sought divestment opportunities to maintain their profitability within the industry average $(12.7 \%$ in selected firms and $12.2 \%$ in database). As much as growth strategies have to be constrained by the capacity of value creation, sustainable profitability cannot be granted out of divestment initiatives. If analyzed from the single perspective of profitability, these firms would be considered in competitive parity. This analysis illustrates the shortcomings of analyzing a single dimension of financial performance.

\section{Dynamics of competition}

Along the period covered by the study the competitive environment changed, alternating phases of expansion and recession. Specifically during the last decade, two recessions (2001 and 2008) influenced the performance results (means and variances) of industries and firms (Bromiley, Navarro, $\&$ Sottile, 2008). Such variations at the industry level should not interfere with the results, according to the methodology applied; however, firms react differently in their capacity to manage instability and such variance at firm level is analyzed below.

At a glance, the competitiveness was almost stable for the full database along the two decades. However, Figure 5 reveals a declining trajectory of competitive advantage among the selected firms, continuously losing position along the 20 years. On the other hand, competitive disadvantage increased among the selected firms, whereas the full database managed to keep it stable over time. The different curves demonstrate opposite phenomena occurring in the two samples and indicating that time and competition affected firms differently. 


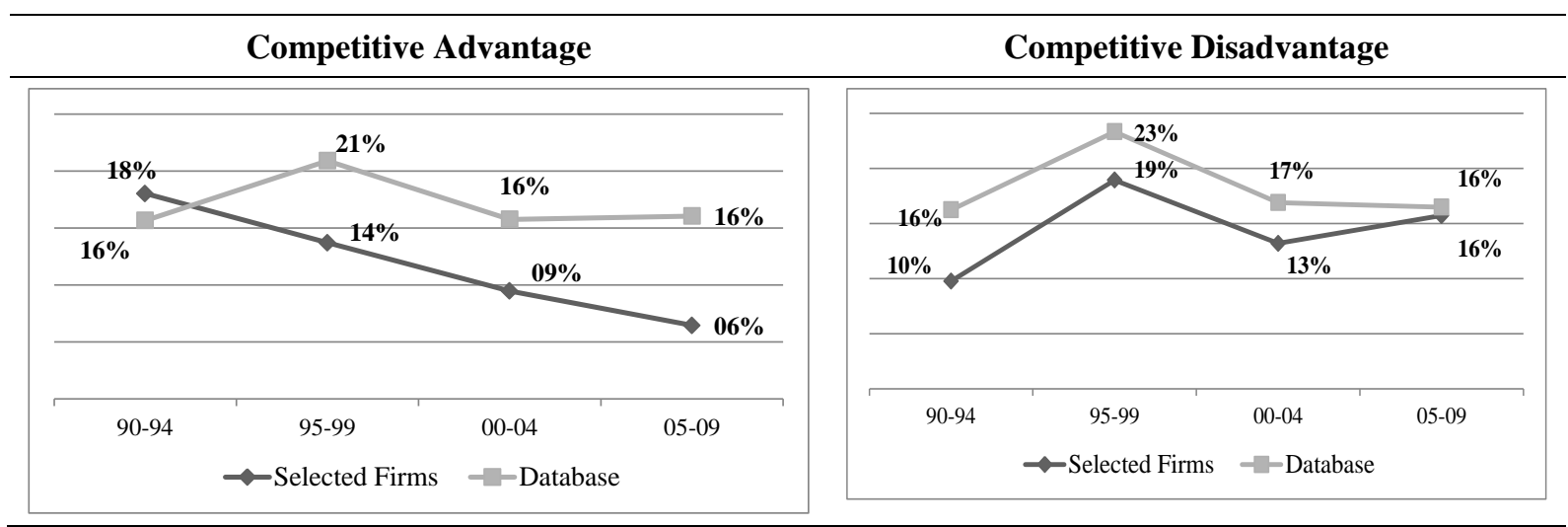

Figure 5. Compared Evolution of Advantage and Disadvantage (1990 -2009).

Even though these results are not enough to support the hypercompetition theory, it does shed light on firms' capacity to remain competitive in time. The findings suggest that the selected firms were more affected by competition than those of the database and lost position over time. New entrants and transient firms demonstrated higher ability to cope with environmental challenges.

Going into more details, the analysis of the combined performance over the four intervals (1990-94, 1995-99, 2000-04 and 2005-09) allows the identification of firms' individual trajectories. The migration along the competitive positions was consolidated into an overall average, and the most relevant movements are here analyzed in two major movements, named primary and secondary movements.

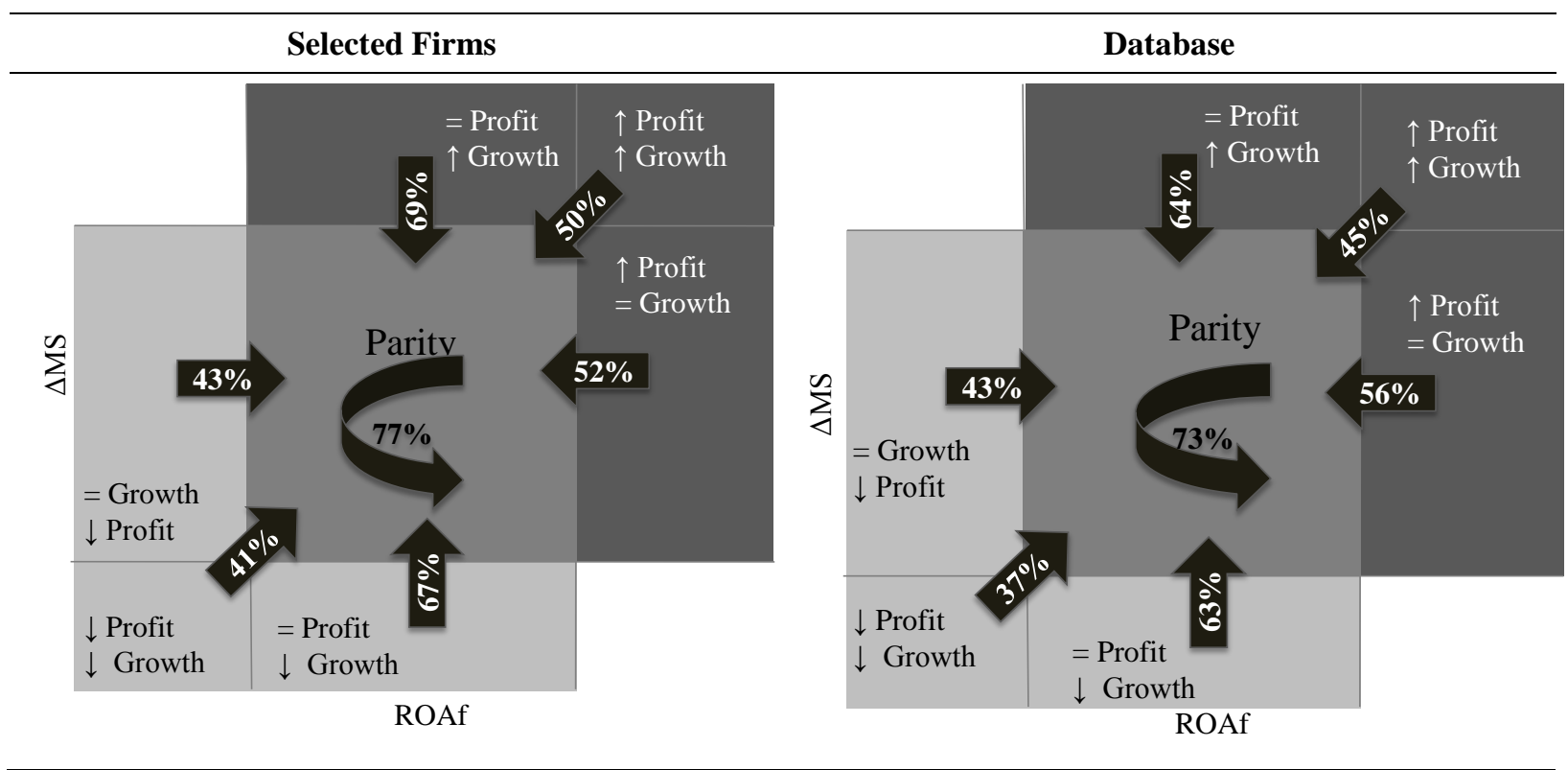

Figure 6. Compared Competitive Dynamic - Primary Movements.

Analyzing the dynamics of competitiveness the first revelation is the strong regression towards the mean (Figure 6), as predicted by studies about performance persistence (McGahan \& Porter, 1997; Powell \& Arregle, 2007). In both samples most of the firms with competitive advantage were not capable of maintaining the position for longer than the initial five-year interval and decayed to industry average performance patterns. At the same time, $77 \%$ of the selected firms remained in the position of competitive parity for more than one interval. Neither advantage not disadvantage proved to be sustainable for most of the firms. The majority of the selected firms positioned in disadvantage managed to catch up with industry-average performance. In these primary movements, the results demonstrate no significant difference between the competitive dynamics of selected firms and the database. 


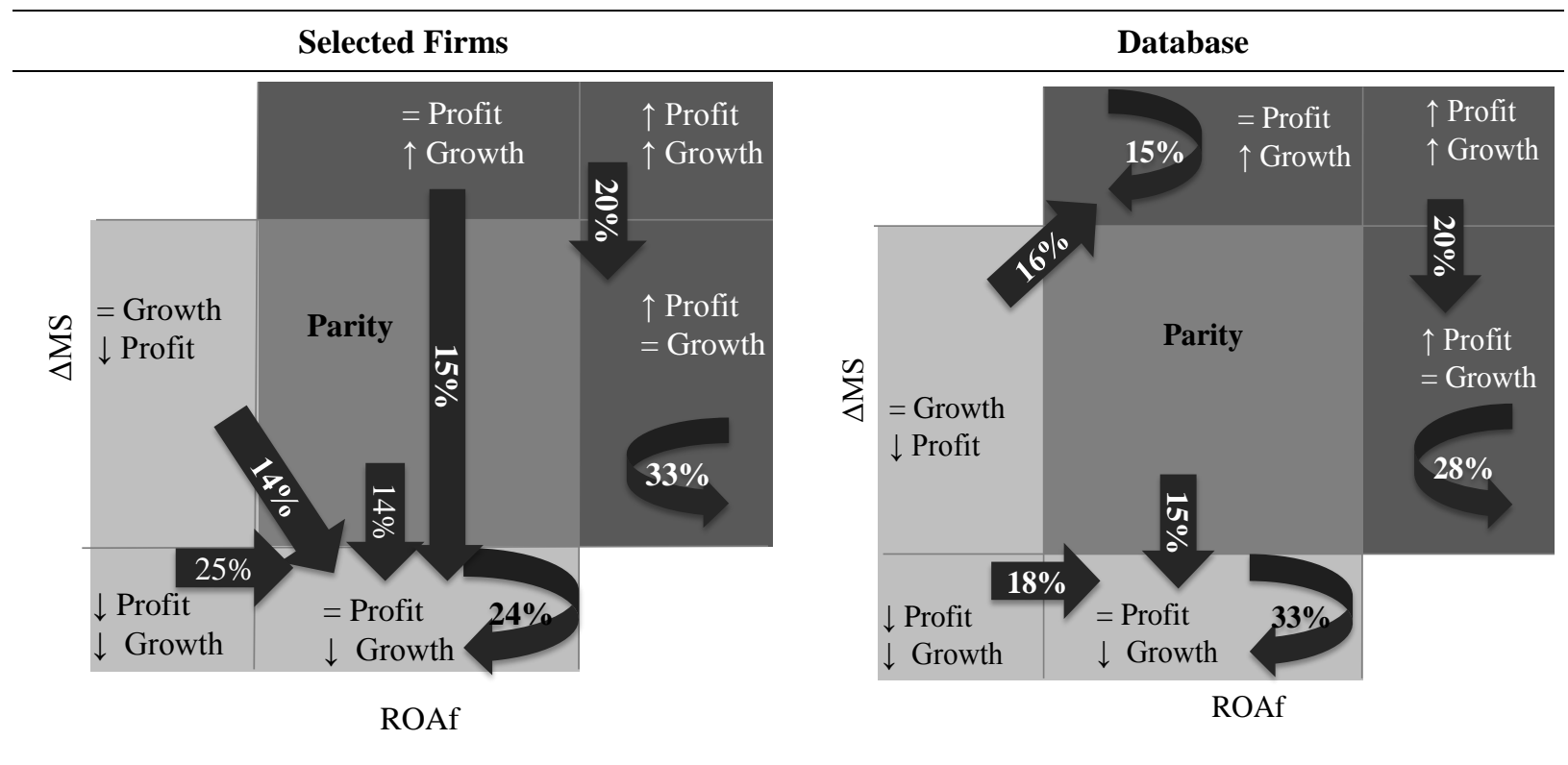

Figure 7. Compared Competitive Dynamic - Secondary Movements.

Albeit the main motions were directed toward the mean, some companies did sustain their position (Figure 7). Out of the selected firms in competitive advantage, 33\% of those with superior profitability and average growth were able to maintain their results in the next interval and for $20 \%$ of those with superior growth and profitability the maintenance of competitive advantage was possible moving to a position of average growth. Differing from the database's firms, the selected firms could not sustain advantage in superior growth and average profitability and $15 \%$ of them decayed to a position of disadvantage with market retraction. Yet, this position of market retraction appeared as the principal destination for firms after the parity and that can be an indicator of specific difficulties of long-lived firms in maintaining growth strategies over time, a pattern that was not as strong in the database.

In general, the results demonstrated great stability in competitive parity, and little sustainability in the extremes. In both samples, the majority of firms with competitive advantage could not sustain the position, demonstrating that the maintenance of advantage for 10 years is an exception that happened for less than $4 \%$ of the firms.

In that sense, five firms stand out for their consistent above normal performance along the two decades. These firms maintained competitive advantage mainly concentrated in position of abnormal profits and average growth, as demonstrated in Table 7.

Table 7

Firms with Competitive Advantage

\begin{tabular}{llcccc}
\hline Firm & Industry & $\mathbf{1 9 9 0 - 9 4}$ & $\mathbf{1 9 9 5 - 9 9}$ & $\mathbf{2 0 0 0 - 0 4}$ & $\mathbf{2 0 0 5 - 0 9}$ \\
\hline Amgen Inc. & Biological Products & $\uparrow \mathbf{P} \& \uparrow \mathbf{G}$ & $\uparrow \mathbf{P} \&=\mathbf{G}$ & $\uparrow \mathbf{G} \&=\mathbf{P}$ & $\uparrow \mathbf{P} \&=\mathbf{G}$ \\
Glaxosmithkline & Pharmaceutical Preparations & $\uparrow \mathbf{P} \&=\mathbf{G}$ & $\uparrow \mathbf{P} \&=\mathbf{G}$ & $\uparrow \mathbf{P} \&=\mathbf{G}$ & $\uparrow \mathbf{P} \&=\mathbf{G}$ \\
Autodesk Inc. & Services-Prepackaged Software & $\uparrow \mathbf{P} \&=\mathbf{G}$ & $\uparrow \mathbf{P} \&=\mathbf{G}$ & $\uparrow \mathbf{P} \&=\mathbf{G}$ & $\uparrow \mathbf{P} \&=\mathbf{G}$ \\
Microsoft Corp & Services-Prepackaged Software & $\uparrow \mathbf{P} \& \uparrow \mathbf{G}$ & $\uparrow \mathbf{P} \& \uparrow \mathbf{G}$ & $\uparrow \mathbf{P} \&=\mathbf{G}$ & $\uparrow \mathbf{P} \&=\mathbf{G}$ \\
Linear Technology Corp & Semiconductors and related & $\uparrow \mathbf{P} \& \uparrow \mathbf{G}$ & $\uparrow \mathbf{P} \&=\mathbf{G}$ & $\uparrow \mathbf{P} \&=\mathbf{G}$ & $\uparrow \mathbf{P} \&=\mathbf{G}$ \\
\hline
\end{tabular}


On the other side, two firms, LTX-Credence Corp. and Network Equipment Tech Inc., were the only ones to have remained in competitive disadvantage along 20 years, and their business continuation challenges the premises of market discipline.

\section{Following the path of some firms}

The proposed model estimates not only the average performance of the samples, but also allows one to determine the precise position of an individual company and to follow its trajectory over time. Some firms' trajectories are interesting in their capacity to overcome difficulties and develop new resources and capabilities, exploring new opportunities (Helfat \& Peteraf, 2003). Others are good illustrations of the difficulties of business survival.

We have selected four well-known firms, from different industries, to illustrate the trajectory: Apple, Dell, Kodak and IBM. In Figure 8, each company is represented by a four-point line starting in the first period (1990-1994) and ending in the last (2005-2009).

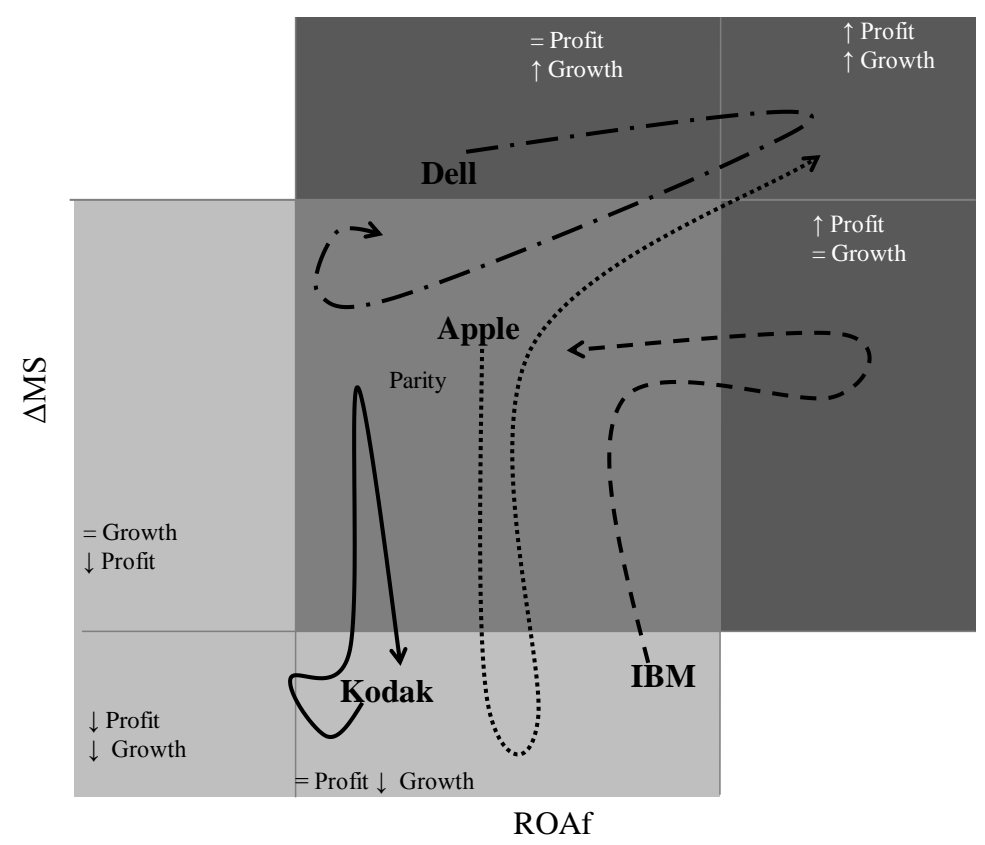

Figure 8. Competitive Trajectory.

Apple's successful history is clearly demonstrated, starting in a position of competitive parity, falling to a competitive disadvantage in the period 1995-1999 and having a remarkable recovery to superior growth and profitability in the last period, due to its highly successful line of products. Dell, on the other hand, starts in competitive advantage, superior growth while practicing competitive prices, offering superior value for its customers and expanding its market share. However, gradually, Dell started raising its prices, appropriating more value and its position moved toward an advantage in superior profit and growth. The recent erosion of Dell's competitive advantage can be noted its descent towards industry parity in last decade. Kodak's struggle towards overcoming technological change is also illustrated in position of competitive disadvantage, briefly recovering to parity, but returning to disadvantage in the last period. Finally, IBM's successful business transition is illustrated on the path from disadvantage to parity and competitive advantage, however this final position was not sustained for long and the firm returned to parity. 


\section{Conclusions}

This article has explored the themes of competitiveness, its dynamics and survival. Competitiveness was analyzed through the implications of value creation and value appropriation decisions in business combined performance. Competitive dynamics were addressed in the analysis of longitudinal data and survival was analyzed in the selection of those firms that remained active along the 20 -year period.

To discuss the dynamics of competition, we applied the multilevel model to a comprehensive database (COMPUSTAT) for a period of 20 years, comparing a sub-set of 993 selected firms with the overall database. The methodology and operationalization of the multilevel model pursued the accommodation of important aspects of firm performance, in decomposing the nested effects of performance spheres of influence and breaking it down into time, industry and firm effects. Having excluded the industry effects, firms' individual performances could be compared in absolute terms. Expanding the understanding of the combined performance, this study allowed us to explore the heterogeneity of firms' strategies between the two samples across the last decades.

There are direct implications from the debate and the results presented here for the empirical study of competitive dynamics and survival:

Growth and profitability can be complementary results of value creation. As the most direct and observable effects of value creation, the combination of profitability and market share variation (growth) reveals the importance of the development of different capabilities along time. Beyond the trade-off relation, the complementarity of performance results can be an outcome of the capacity for exploration and exploitation of market opportunities (Cao et al., 2009; Taylor \& Helfat, 2009).

As Fleck (2010) stated, firms should manage growth responsibly. Along the same lines, value appropriation strategies, in profitability results, should not jeopardize the exploration of growth opportunities.

Competitive Advantage may not persist. For both samples, the analysis of competitive dynamics demonstrated that most firms could not maintain their position over 10 years. Growth strategies seemed even more fragile among the selected firms and $15 \%$ of them decayed to a position of market retraction while maintaining an average profitability. This can also be an indication of incumbents' weak growth capacity when facing new competitors in the market. One also has to consider the possibility that these patterns are influenced by chance, as explored by Denrell (2004).

Competition affects firms differently over time. While the overall database revealed a steady pattern of competitive advantage and disadvantage along the 20 years, results from selected firms reveal a retrenchment of advantage over time. The findings suggest that increasing competition does not affect all firms equally and that for long-lived firms the position of parity was crucial for survival.

Survival might be another dimension of performance. The analysis of selected firms raised some questions about this other dimension of performance: the time dimension (Richard, Devinney, Yip, \& Johnson, 2009). Firms compete for resources and markets, seeking to cover their costs and survive (Rumelt, Schendel, \& Teece, 1991). Though not revealed in competitive advantage, it is possible that the value created by these companies is manifested in their survival. That is, the maneuver of performance results can hide the effects of competitive advantage, which ultimately also protect the company from competitors. However, it is possible that different methodologies may be needed to investigate value creation with low performance, in this study we focus on only what is revealed in profit and growth results.

Finally, it is important to recognize that the number of long-lived companies may still be higher than identified, since in the process of mergers and acquisitions companies may have changed their 
identification and thus were not recognized in this study. We also recognize that the effects of competitive advantage in organizational performance may be larger than how it was operationalized here and that the conclusions are restricted to the samples examined.

Competitive advantage continues to be a challenging topic in strategic management research. Although this article contributes by highlighting the importance of simultaneously examining growth and profitability as performance outcomes and by examining long-lasting firms in more detail, its limitations suggest several opportunities for future research by exploring different methods and samples. An interesting question would be the pattern of competitive advantage in emerging countries, like Brazil or China.

\section{References}

Baumol, W. J. (1962). On a theory of expansion of the firm. The American Economic Review, 52(5), 1078-1087.

Besanko, D., Dranove, D., Shanley, M., \& Schaefer, S. (1996). Economics of strategy. Hoboken: NJ: John Wiley \& Sons, Inc.

Bowman, C., \& Ambrosini, V. (2000). Value creation versus value capture: towards a coherent definition of value in strategy. British Journal of Management, 11(1), 1-15. doi: 10.1111/14678551.00147

Brandenburger, A. M., \& Stuart, H. W., Jr. (1996). Value-based business strategy. Journal of Economics \& Management Strategy, 5(1), 5-24. doi: 10.1111/j.1430-9134.1996.00005.x

Brito, R. P. de, \& Brito, L. A. L. (2012). Vantagem competitiva, criação de valor e seus efeitos sobre o desempenho. Revista de Administração de Empresas, 52(1), 70-84. doi: 10.1590/S003475902012000100006

Bromiley, P., Navarro, P., \& Sottile, P. (2008). Strategic business cycle management and organizational performance: a great unexplored research stream. Strategic Organization, 6(2), 207-219. doi: 10.1177/1476127008090011

Burgelman, R. A., \& Grove, A. S. (2007). Let chaos reign, then rein in chaos-repeatedly: managing strategic dynamics for corporate longevity. Strategic Management Journal, 28(10), 965-979. doi: $10.1002 / \mathrm{smj} .625$

Buzzell, R. D. (2004). The PIMS program of strategy research: a retrospective appraisal. Journal of Business Research, 57(5), 478-483. doi: 10.1016/S0148-2963(02)00314-4

Cao, Q., Gedajlovic, E., \& Zhang, H. (2009). Unpacking organizational ambidexterity: dimensions, contingencies, and synergistic effects. Organization Science, 20(4), 781-796. doi: 10.1287/orsc. 1090.0426

Coff, R. W. (1999). When competitive advantage doesn't lead to performance: the resource-based view and stakeholder bargaining power. Organization Science, 10(2), 119-133. doi: 10.1287/orsc.10.2.119

Coff, R. W. (2010). The coevolution of rent appropriation and capability development. Strategic Management Journal, 31(7), 711-733. doi: 10.1002/smj.844

Crook, T. R., \& Combs, J. G. (2007). Sources and consequences of bargaining power in supply chains. Journal of Operations Management, 25(2), 546-555. doi: 10.1016/j.jom.2006.05.008 
Cubbin, J., \& Leech, D. (1986). Growth versus profit-maximization: a simultaneous-equations approach to testing the marris model. Managerial \& Decision Economics, 7(2), 123-131. doi: $10.1002 /$ mde. 4090070209

D'Aveni, R. A. (1994). Hypercompetition: managing the dynamics of strategic maneuvering. New York: Free Press.

D'Aveni, R. A., Dagnino, G. B., \& Smith, K. G. (2010). The age of temporary advantage. Strategic Management Journal, 31(13), 1371-1385. doi: 10.1002/smj.897

Denrell, J. (2004). Random walks and sustained competitive advantage. Management Science, 50(7), 922-934. doi: $10.1287 / \mathrm{mnsc} .1030 .0143$

Dyer, J. H., \& Singh, H. (1998). The relational view: cooperative strategy and sources of interorganizational competitive advantage. Academy of Management Review, 23(4), 660-679. doi: $10.2307 / 259056$

Fleck, D. L. (2004). Crescimento, dominância continuada e declínio da empresa: insights das histórias da General Electric e da Westinghouse (Edição Especial). Revista de Administração Contemporânea, 8, 79-106. doi: 10.1590/S1415-65552004000500006

Fleck, D. L. (2010). Why we should dare to manage growth responsibly. Management Decision, 48(10), 1529-1538. doi: 10.1108/00251741011090315

Geroski, P. A., Mata, J., \& Portugal, P. (2010). Founding conditions and the survival of new firms. Strategic Management Journal, 31(5), 510-529. doi: 10.1002/smj.823

Ghemawat, P., \& Rivkin, J. W. (2006). Creating competitive advantage. Boston: Harvard Business School Note.

Hannan, M. T., \& Freeman, J. (1984). Structural inertia and organizational change. American Sociological Review, 49(2), 149-164.

Helfat, C. E., Finkelstein, S., Mitchell, W., Peteraf, M. A., Singh, H., Teece, D. J., \& Winter, S. G. (2007). Dynamic capabilities: understanding strategic change in organizations. Malden, MA: Blackwell Pub.

Helfat, C. E., \& Peteraf, M. A. (2003). The dynamic resource-based view: capability lifecycles. Strategic Management Journal, 24(10), 997-1010. doi: 10.1002/smj.332

Jacobson, R. (1990). Unobservable effects and business performance. Marketing Science, 9(1), 74-85. doi: $10.1287 / \mathrm{mksc} .9 .1 .74$

Jensen, M. C. (1986). Agency costs of free cash flow, corporate finance, and takeovers. American Economic Review, 76(2), 323-329.

Lindgreen, A., \& Wynstra, F. (2005). Value in business markets: what do we know? Where are we going? Industrial Marketing Management, 34(7), 732-748. doi: 10.1016/j.indmarman.2005.01.001

Lippman, S. A., \& Rumelt, R. P. (2003). A bargaining perspective on resource advantage. Strategic Management Journal, 24(11), 1069-1086. doi: 10.1002/smj.345

March, J. G. (1991). Exploration and exploitation in organizational learning. Organization Science, 2(1), 71-87. doi: $10.1287 /$ orsc. 2.1 .71

Marris, R. (1964). The economic theory of managerial capitalism. London: Macmillan. 
McGahan, A. M., \& Porter, M. E. (1997). How much does industry matter, really? Strategic Management Journal, 18(S1), 15-30. doi: 10.1002/(SICI)1097-0266(199707)18:1+<15::AIDSMJ916>3.0.CO;2-1

McNamara, G., Vaaler, P. M., \& Devers, C. (2003). Same as it ever was: the search for evidence of increasing hypercompetition. Strategic Management Journal, 24(3), 261-278. doi: $10.1002 / \mathrm{smj} .295$

Pacheco-de-Almeida, G. (2010). Erosion, time compression, and self-displacement of leaders in hypercompetitive environments. Strategic Management Journal, 31(13), 1498-1526. doi: $10.1002 / \mathrm{smj} .896$

Peng, M. W., \& Heath, P. S. (1996). The growth of the firm in planned economies in transition: institutions, organizations, and strategic choice. Academy of Management Review, 21(2), 492528. doi: $10.2307 / 258670$

Penrose, E. (1959). The theory of the growth of the firm (3th ed.). Oxford, UK: Oxford University Press.

Peteraf, M. A., \& Barney, J. B. (2003). Unraveling the resource-based tangle. Managerial and Decision Economics, 24(4), 309-323. doi: 10.1002/mde.1126

Porter, M. E. (1985). Competitive advantage: creating and sustaining superior performance. New York: Free Press; Collier Macmillan.

Powell, T. C. (2001). Competitive advantage: logical and philosophical considerations. Strategic Management Journal, 22(9), 875-888. doi: 10.1002/smj.173

Powell, T. C. (2003). Varieties of competitive parity. Strategic Management Journal, 24(1), 61-86. doi: $10.1002 /$ smj. 283

Powell, T. C., \& Arregle, J.-L. (2007). Firm performance and the axis of errors. Journal of Management Research, 7(2), 59-77.

Priem, R. L. (2007). A consumer perspective on value creation. Academy of Management Review, 32(1), 219-235. doi: 10.5465/AMR.2007.23464055

Raudenbush, S. W., \& Bryk, A. S. (2002). Hierarchical linear models: applications and data analysis methods (2nd ed.). Thousand Oaks: Sage Publications.

Richard, P. J., Devinney, T. M., Yip, G. S., \& Johnson, G. (2009). Measuring organizational performance: towards methodological best practice. Journal of Management, 35(3), 718-804. doi: $10.1177 / 0149206308330560$

Rumelt, R. P., Schendel, D. E., \& Teece, D. J. (1991). Strategic management and economics (Special Issue). Strategic Management Journal, 12, 5-29. doi: 10.1002/smj.4250121003

S\&P Capital IQ - McGraw Hill Financial. (n.d.). Data base (COMPUSTAT). Retrieved from https://www.capitaliq.com/home/what-we-offer/what-you-can-do-with-it/streamlinequantitative-research/research-insight.aspx

Steffens, P. R., Davidsson, P., \& Fitzsimmons, J. R. (2009). Performance configurations over time: implications for growth and profit oriented strategies. Entrepreneurship Theory and Practice, 33(1), 125-148. doi: 10.1111/j.1540-6520.2008.00283.x

Taylor, A., \& Helfat, C. E. (2009). Organizational linkages for surviving technological change: complementary assets, middle management, and ambidexterity. Organization Science, 20(4), 718-739. doi: 10.1287/orsc.1090.0429 
Teece, D. J., Pisano, G. P., \& Shuen, A. (1997). Dynamic capabilities and strategic management. Strategic Management Journal, 18(7), 509-533. doi: 10.1002/(SICI)10970266(199708)18:7<509::AID-SMJ882>3.0.CO;2-Z

Vargo, S. L., \& Lusch, R. F. (2004). Evolving to a new dominant logic for marketing. Journal of Marketing, 68(1), 1-17.

Wiggins, R. R., \& Ruefli, T. W. (2005). Schumpter's ghost: is hypercompetition making the best of times shorter? Strategic Management Journal, 26(10), 887-911. doi: 10.1002/smj.492 